\title{
Newspaper Recollections 1886-1936
}

\section{By Ora Williams}

With this article we again greet in absentia an old friend whose close association with the ANNALS OF Iowa continued even after the years 1938 to 1946 when he was the editor. The material here is from a speech given to the Des Moines Pioneer Club January 25, 1936.

Rich indeed am I in recollection and retrospect for having contacted the art of newspaper making in the romantic era. Happy also am I for having jostled elbows with the printer-editors who in the formative period of Iowa helped to weave the pattern of our homeland.

Newspaper making on the frontier was not a business, it was an avocation or a pastime. A little way back from the edge of the prairie it became a channel for the outpouring of the passions of the crusaders. Let others prate of publishing profits or gloat over the achievements of nicely balanced typewriters and linotypes. I cannot testify. I am here to sing praises of the newspaper makers of yesteryear, rough and ready artisans, their schooling with the composing stick, strong-armed by the hand press. From their unswept dens there radiated little circles of intellectual waves, overlapping sometimes and crashing on the crags.

Perched on a crippled stool behind a battered desk there was a genius who decided what stories went into the paper or were kept out. His office gave him a definite social standing in the community quite apart from his threadbare coat. The editor was on all committees. His name stood out on petitions for this and that. He was one of the judges at the Sunday-school picnic. The caucus was never called to order until he had sharpened his pencil.

The newspaper as such was an institution. It symbolized one of the estates of the realm. It was fully recognized by the workers planning and building a wholesome social and economic order. Community enterprise leaned on newspaper friendliness. Deference to the print shop and its output ran right down the line. Even the "printer's devil" with his little rule had Open Sesame to the oyster supper at the 
church, and he was kindly treated at the door of the circus. These things I can testify to.

The Iowa you know by contact and tradition, the young Iowa glorified in the legends to which I listened by blazing hickory fires on stone hearths-Iowa, my Iowa and your Iowa, was built on virgin soil far from the ocean shores where the flotsam of foreign debris often clogs the currents of Americanism. The foundation was good. We have seen first-class workmanship go into the structure. This valley of the big rivers is the heart of the continent. In this land of all the industries, at the time we love to think about, the plan and the principles of the founding forefathers was not a matter of schoolroom debate. It was something just lived.

The trail blazers and the sodbreakers brought good blood to the task of hewing out their own social security. With all their diverse temperaments and talents they were tolerant. They had to be. They came from everywhere-from the new states of the old Northwest, from the seaboard colonies, from the borders of the southland, from old world areas choked by absolutism or racked by revolutions. They clashed in their opinions and disagreed in doctrines, but by necessity they whipped them all into magnificent team work. They exemplified, but did not preach, brotherhood.

With the town and city builders, and the church and school organizers, came the editors with print shop equipment in bags and boxes. If there was to be history making along the Indians trails, there was also to be history recording as and when made. It was a joyous outlook. With stubby pencils and sticky type they shouldered a great responsibility. And they did not fail. They established a tradition for fidelity that was potent from chapel to press room. Mine was the privilege of sitting at the feet of those who followed that tradition and interpreted it nobly.

Into this Coon Forks settlement that to my grandfather was always "The Fort" where he swapped his shoats for ox-yokes and bargained for brown sugar and cowhide boots, I came off the high prairie to the west and thrust myself into an inky whirlpool. The old order was not quite gone, but it was on the way, and the "Fourth Estate" was taking 
on some of the drab colors with which the counting room was to decorate the editorial sanctum. Opportunity lay across my path as a challenge. This new capital of a young state was pulsating with activity, with ambition, with confidence. Everyone was busy. From five different print shops there were issued five daily papers. On the dead-rack the dust was hiding the discarded headings of others that had been but were not-the Star, the Journal, the Gazette, the Bulletin, the Record, the Republican, the Commonwealth, the Citizen, the Statesman. Presses turned weekly or monthly to meet the demands of almost every brand of reform or special interest. It was a gay time in the printing game.

Iowa had elections every year then. Members of the Twenty-first general assembly were making their way through snowdrifts to the halls of legislation. It was a cold January, that of 1886, when after a military flourish the glittering inaugural parade moved slowly across the river and up the hill, with black horses and shiny carriages to the rotunda beneath the golden dome. The new governor and his lieutenant were given the oath of office by a chief justice who taught school in the Penoach country not far from where I first heard the boom of the prairie chicken. The fife and drum echo gave us a "captain" as presiding officer in each house of the legislature.

I will commence now where I did then, with an excursion into the office of the Hawkeye Blade. Yes, a daily paper, with press dispatches, a morning paper quite creditable to a city of 35,000 people! The Blade was of the spirit of sharp rivalry and free competition of the times. Starting a newspaper was always in the game. The Blade was the child of Lowry W. Goode. He had as associate in the venture, as for many years after in city development, Dr. E. T. Likes, now a member of this club and on this program. Lowry was assisted by his brothers Fred and Clan.

My job was to do everything not done by somebody else. I was not a novice. With the favor of an eminent lawyer I had stepped out of a schoolroom to be part owner and part editor of a weekly paper before I could vote. I had "learned the case" from my own copy. I had taken my turn as wandering printer, after the manner of the times, doing any- 
thing and everything on daily papers in the Northwest. I had come to Des Moines by invitation. As a handyman I suppose I would have classified as managing editor or something. I gathered up the copy in an office in the corner of the old Exposition building way out on Walnut street and took it to a den in a basement on Fourth and fitted things together. I ran the errands neglected by others. I wrote the heads and read the proofs. Sometimes I had to finish out portions of the editorial fillers furnished by Will Porter when the hand of the veteran historian became too shaky to follow his brilliant brain.

In a way the long-forgotten Hawkeye Blade was a connecting link between the things that were and the things that were to be. Rather dimly we sensed the transition of the time. Men and ideas were being shifted to proper places. Editors as well as printers moved easily from one workshop to another. The Hawkeye Blade was not Lowry Goode's first love, his restless ambition led him to try for a newspaper organ all his own. But time dulled the edge of the Blade. History will always accord to its editor a high place among the doers of good for Des Moines.

When the Blade ceased to cut its daily swath I went with the subscription list and other junk to the Iowa State Leader, at that time in the hands of $\mathrm{W}$. H. Welch and John Watt, but struggling to maintain a semblance of the high authority it once had under Mr. Goode and Mr. Witmer. It had a fine tradition running back to the time of Barlow Granger's brightly shining Star, a jewel among first things. It had survived changes in name, changes in editors, changes in ownership and numerous fires. About this time John Olson and A. H. F. Ziegler sought to put new life into it with La Vega G. Kinne as nominal editor at a time when he had not aspired to the supreme bench. It had suffered the battering of Frank Garrity, later it fell to Henry Stivers and so on down.

About this time the Iowa Capitol was being edited by the scholarly John R. Sage, already dreaming of the value of an Iowa crop service, and he was assisted by the kindly Clarence Wilson, who had drifted down from Madison county and broke into the legislature. Wilson had joined 
with George McCracken and Charley Painter in starting the Daily News. Changes had taken place and the peppery little handbill had become the medium through which John J. Hamilton displayed a pernicious activity, later to have the assistance of his talented sister, Mrs. Durley and her husband. Both the Capitol and the Neus sought to capitalize the provincialism of the "east side," but both moved across the river and attained high value before passing out of the picture.

I was assigned a desk and given a key in the reporters' gallery of the State senate; but after the fashion of the time, I made a quick shift of my newspaper connections. By invitation and through the favor of my recent employer of the Blade I crossed Court avenue and took a job that lasted a good while and proved to be always agreeable. I counted myself fortunate in having joined the staff of the old Iowa State Register, symbol of substantial achievement.

With scant confidence I climbed the creaky stairway one flight beneath the clock tower that never had a clock.

Now fifty years afterwards I fancy that I carried with me the notion prevalent and much cultivated in every one of the other print shops that somewhere hidden beneath the clock tower was the "Den of the Iniquitous Regency." They always spelled it with a capital "R." That was no offense. Had not the term of derision been haughtily adopted with some show of pride?

"The Regency," said its great chief to me, "is at least a Regency of brains and not of beef."

His path to the high seat had been straight. James S. Clarkson, or "Ret," was a country school teacher, learned the printer's case as a foundation for his life work, fell under the spell of "Blind" Dixon and helped him in his misfortune, tried his hand timidly as reporter and when the chance came he was installed as a substitute in the inner sanctum where he had made good. He was in his prime, which is saying much. Envy had branded the Regency as selfish and ruthless in the political arena. The newspaper on which the power rested was declared to be narrowly partisan, illiberal, harsh. This repute should be set aside. Ret Clarkson was earnest, forceful and positive, but he 
was far from being a dictator. He towered in intellect, but he was tolerant-unless there was an issue of right and wrong. He had strong convictions. He ably defended his own side. He faced the foe when challenged. He did not complain in defeat. But he was generous to those with whom he failed to agree. He had the faults and the virtues of a knight errant of democracy.

Neither by inheritance nor early political training had I been fitted for a part in the scheme of things symbolized by the clock tower. To Ret Clarkson I admitted as much, but had no apology. The examination was brief but I passed.

"I do not care how anyone in my service thinks or votes," he said, "all I ask is that the work be well done and no offense be given my friends."

The wisdom of this liberal policy was proved by many warm friendships that crossed party and other lines. For instance, I recall a certain sharp political fight which was brought to a head in just one ward of Des Moines. The effort was to cripple him at home so as to unseat him from the national committee of his party where he was already recognized as a national figure. Ret went up to his composing room and enlisted the enthusiastic support of the printers without regard to party affiliations, then had Pike Lynch of the fire department ring the bell that brought victory in the little primary. Loyalty to the Regency and its fighting chief could be counted on in every crisis.

In the game of politics, where principles were at stake, there were hard licks to give and to take. Sometimes the punches were below the belt. There was much chuckling in the secret nooks of the high chapel over a rather lowdown trick that upset the schemes of the not overly nice political opponents. A sensational exposure was to be made of alleged hard heartedness on the part of the Republican candidate for governor. A page had been prepared for the Democratic newspapers to be sprung on a date certain. Someone crawled through a transom at the "ready-print" house and carried off the "mats." They were delivered across the street to the Register, and the whole page printed prematurely. With the chance for answering blasts and dis- 
proof, the sting intended was largely lost. There are few new moves in the political game.

There was coolness down at the corner towards the administration of the highly independent new governor, but a desire, for party good, to be helpful and to cooperate. I recall an incident, the details of which were never put into circulation. In the distant city of Washington, Congress had for the first time fallen into the hands of the ex-brigadiers of the Confederate army. They were riding high. As has happened many times since, their solid block seemed invincible. One night the wires carried an item to the effect that the new deal of the time included a plan to have returned to the southern states the battle flags captured in war by federal armies. Immediately there went over the same little wire a defiant challenge from the "Fire Alarm" governor of Ohio to the effect that sending back of the flags would have to be over the prostrate forms of those who had upheld the union.

The whole story came late at night. Ret promptly put on the wire a similar challenge and denunciation from the governor of Iowa-then sent out to wake the governor up and tell him about it. And so history is sometimes made that way.

Another line of anecdotes illustrated the spirit of the sanctum. It was not new in the newspaper art, nor is it yet forgotten, that hard fighting for principle and kind personal consideration go hand in hand. The problem of what to do about sale of intoxicants left its trail of embarrassments. Ret Clarkson loathed the traffic with all its evils. He said so, and said it so that everybody knew. But he was reviled for candid effort to save from destruction "the biggest distillery in the world," located in Des Moines. He denounced the vending of liquors for drinking. He had no patience with the "searchers" who were a corps of constables making a business of getting evidence by rough methods and resorting to lawlessness. There was one hectic day when a mob with a rope followed Constable Pierce, heavily armed, all about town, both sides waiting for somebody to start something. I trailed them and somewhat dis- 
appointed wrote up the story coldly; which had the approval of the chief.

No one was more welcome to the sanctum under the clock tower than the excitable editor of the Staats-Anzeiger, the special organ of "personal liberty" which was the slogan of the traffic just then. They agreed to disagree, and that was all there was to it. Col. Eiboeck and Judge Nourse, Fred Lehman and Mrs. McMurray-at the extremes of the age old problem of intoxicants-were all equally free to cross the threshold.

The way it happened that the Regency became such was an office secret. Disagreement over the playing of the political game brought on a crisis in family relationship and compelled a readjustment. Jacob Rich, the political mentor of the old Third district, related to me the details long afterwards, though he probably did not tell all. The story was not entirely new.

When the Mills \& Co. firm found running a daily newspaper interfered with their extensive printing business, sale was made to the Clarksons, father and two sons. Coker F. brought down from Melrose Farm, in Grundy County, the ways of the Hoosier politics he had learned in Brooksville on a country weekly. The youngest of the trio was already at the editorial helm. Some time later a senatorial contest within the party loomed large. Nobody even thought of refusing to "take sides" or of failing to get into the midst of the fracas. Decision was for the master mind of the partnership-but whose? The farmer-editor had always sat in the front seat. He had not realized how quickly a country school teacher might grow into something else. It was embarrassing all round.

For good reasons the senior was devoted to the grand old statesman of Mt. Pleasant who had been close to President Lincoln. The junior political forecaster had been watching the rising star of a younger man at Dubuque with Ohio affiliations. Within this line of cleavage the Regency became a reality. The rugged Hoosier brought his big fist down on the editorial desk and made it known that so long as he was head of the firm they were going to be for Harlan. The wisdom of age was pitted against the vision of 
youth. Something had to be done. The father cheerfully made a give-or-take offer. He probably smiled as he remembered that neither of "the boys" had invested anything more than unbounded confidence, and that probably they had no credit at the bank.

The deadlock was broken quickly. A few days later, so Mr. Rich told me, Ret stepped off a train from Dubuque, laid down the money and took up the option. The election of Allison started a new chapter in Iowa politics. Many of the later chapters had other motives and ended differently. For years afterwards, and so long as he lived, the stern and versatile "Father Clarkson" retained a fine connection with the paper, chiefly as farm editor.

This was not the last time Ret Clarkson capitalized on the intense admiration his ability evoked among the politically ambitious. No one knew better his masterly leadership than his old friend John S. Runnells. No one was more in need of superlative newspaper talent than his idol James G. Blaine. When Ret turned the editorial helm over to his brother, it was with intent he would soon be editor of a newspaper of national influence in either New York or Chicago. In after years, as he sat in his office as head of the Pullman company, Mr. Runnells told me of having, on behalf of a syndicate, offered a million dollars for the Chicago Tribune. At that time the offer seemed extravagant. But the veteran editor who had built up the giant business merely shook his head and wrote another editorial. The offer was raised to a million and a half. That was at least worth considering. In the end, Joseph Medill gave the answer that so long as he lived the Tribune would remain with him and for his family.

If the offer had been accepted, with the persuasive Clarkson backing the magnetic Blaine, who knows how greatly the story of American politics might have been changed?

I felt personal disappointment that the intent was never translated into action. When Ret bade good-bye to the clock tower, he paused on the stairway to whisper to me that some time he would send for me. Perhaps that was just a way of scattering good cheer. I did not think so. I felt justified in attributing his kindly interest to an incident I can 
now relate, not alone to satisfy my egotism, but revealing the ways of the editor-in-chief and his appreciation of resourcefulness. I had hardly become warmed to my seat in the "city room" that cold winter of fifty years ago when late one night Senator C. H. Gatch, eminent lawyer, was ushered into my room. He had been telling the chief about the latest turn in the famous litigation over the Des Moines River land grant. I was to get the facts and write the story.

Like many another, the senator apparently becarne shy at sight of a reporter's pencil. He looked me over and perhaps judged me as one too recently from the small town. He would excuse himself, so he said, and tomorrow bring in the story all written out with accuracy. I might not have looked it, but I did know that was not a good newspaper way. I decided differently. I threw my pencil down and cocked my feet on the pine-top table. The senator, thoroughly disarmed, but filled to the brim with his story of victory, unburdened himself. He left with a promise for the next day. But the next day he and the editor-in-chief came rushing into my room and laid down the morning paper with a column-long story.

"Who wrote that interview?" was asked of me rather abruptly.

I confessed. There it was-facts and figures and dates galore. Ret smiled and went back to his room.

"Well," said the senator, "you certainly did a fine job; but however did you get all that without making a pencil mark?"

Ever afterwards the senator was my friend. And I had a fancy that Ret never forgot about the incident.

Out from that dimly lighted room-for we were even then grumbling about the quality of the gas-I went one night to a hotel and sat unabashed in the presence of one of Iowa's greatest jurists and helped him with a speech. This was Samuel F. Miller, who had been placed on the supreme bench by favor of Abraham Lincoln. He had spoken at the formal dedication of the Iowa supreme court rooms. I had stood on a chair at the rear and made a few notes. The speaker had no manuscript. He kindly consented to help us out. As I sat facing him I was deeply impressed 
by his massive head and the giant intellect within. But the jurist laid aside his robes and was again the country doctor he had been at one time and he treated me with with charming courtesy.

"O yes," he would say, as I jogged his memory from my scrappy headings, "I remember now."

Taking his cue from my notes he rebuilt his dedication address and dictated it line by line with great care. As thus made by my help and transcribed by Charley Dahlberg the speech went into the paper and into the books. You will find it in standard collections of choice judicial oratory-an appraisement of the country lawyer, a tribute to the bar of Iowa.

Many and varied are the experiences of an active newspaper life. Always the ordor of rum and tobacco was taboo in the inner sanctum beneath the clock tower. Not yet had the tempo of life been set to the swagger of the silver screen. One day I saw Henry Clay Dean going away and filling the hall with the smell of a Missouri cob pipe. $\mathrm{He}$ was a truly great orator of the old school-versatile, erratic, vitriolic. Beneath an uncouth exterior there were many jewels of thought. "Dirty Dean" he was called.

"Dean is the only man I know," I heard Ret say, "who is welcome to sit in my office and smoke."

A current story about Dean was probably libelous. He had come from his den at "Rebel Cove" to lecture at Winterset. Judge Leonard was so shocked by the visitor's soiled appearance that he loaned him a clean shirt, which the Missourian kept when he went away. Another lecture season came and again the visitor needed a clean shirt, and an exchange was effected. The next day the judge found to his chagrin that his own laundry mark was on the soiled garment left by the orator. We never knew whether this was just one of "Long John's" characteristic jokes. Anyway Dean is said to have well deserved his nickname.

From the standpoint of a small town printer who had learned about capitals and commas in a one-room McGuffey school, it was better than a university course to be privileged to contact the currents of humanity surging 
through an ambitious little city. For me it was a five-year course in practical civics. A colorful parade of little men with big ideas marched past Fourth and Court Avenue. The den under the berated clock tower was an informal club for the forgathering of those who wanted things done

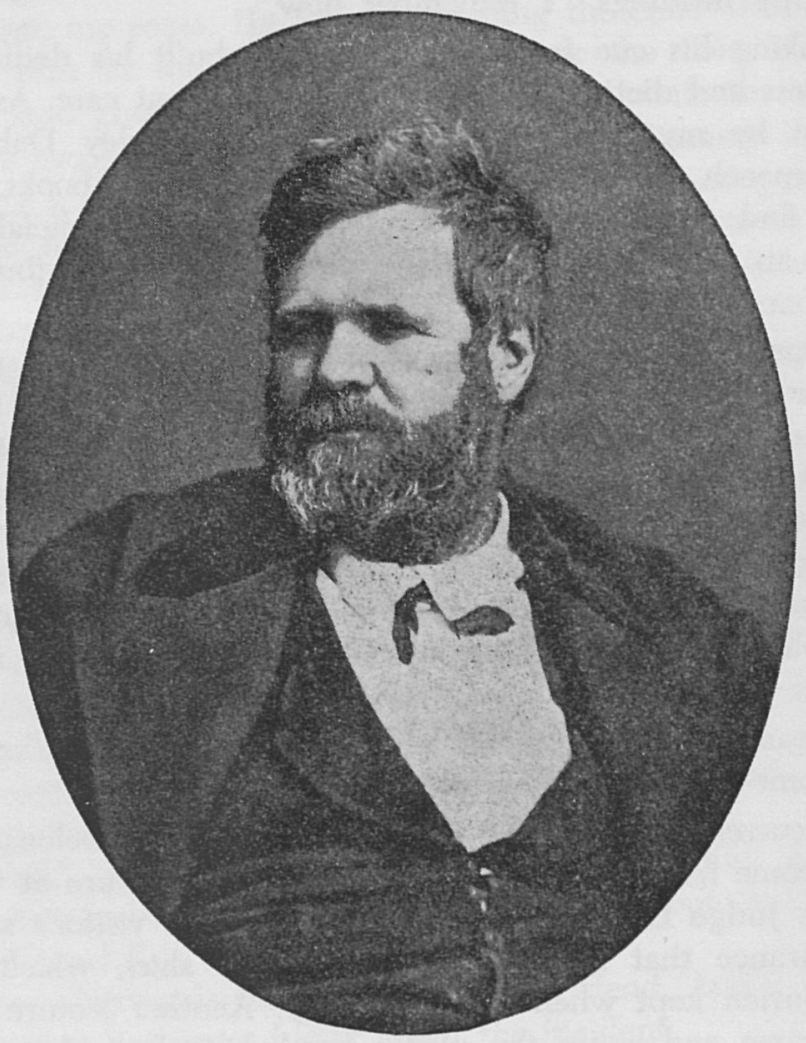

Henry Clay Dean

"Dirty Dean"-descriptively nicknamed militant Iowa copperhead.

or not done. They paused here to get or to give advicemen and women with or without politics, religion, business. The lights and shadows of a glorious past fixed the traditions of the workshop. It was the clearing house of ideas. Back of it were four decades of getting ready. The horizon was rosy with tints of the coming triumphs.

What a pity that while we were at the hard tasks we did 
not more often pause to gather from the quiet corners the wealth of stories of human interest with which the pioneer life was enriched. But we were busy. Let history wait.

The den was a busy place. Long hours and late were the rule. All the "copy" sent from second to fourth floor was on soft paper made with hard pencils. It was always good for a smile in the chapel when a fresh tramp printer drew a few sheets of editorial writing. All hands noted the bewilderment of one trying for the first time to decipher the queer characters. Even the veterans found the going hard. I have seen the charming Mrs. Clarkson moving quietly from alley to alley and looking over the shoulders of the printers to interpret to them the mysterious writing. Then I have heard the cheerful click of the jig she danced to mark the homeward turn after midnight. To his credit be it said, that Ret did install one of the new-fangled writing machines and dictated to his secretary, Mrs. Ivy, who wrought the printed lines much to the delight of the journeymen printers.

The great press in the basement was a wonder-working monster that printed direct from the hand-set type made up in pages on a rounded "Turtle" curved to the arc of the big cylinder. And today's paper was always printed today.

It was my good fortune to have been inducted into the ways of the Regency and its newspaper organ under the careful tutelage of one who happily survives in retirement in the western city of the roses. This was James A. Miller, a typical rough and ready newsman of the school that never shaded a story for a box of cigars. Not long ago I incidentally had a visit with him in the office of Frank Woods, former Iowa congressman, in Pasadena. Miller's later newspaper work culminated at Long Beach. He had quite ably followed a long line of good newspaper men-Pierson Bristow, who took a clerkship in Washington and kept on singing in the church choir; the famous "Blind" Dixon, much beloved; Al Swalm, picturesque in newspaper work and useful in the consular service; Lafe Young, always able to make himself well understood; Ret Clarkson himself and others.

My chance had come to me when Tom Cox, genial and convivial Englishman, yielded once too often to the temptation that was thrown in our faces at every corner. Will Van 
Antwerp, son of a straight-up minister, came about the same time, but went away with Miller and Conaway to try the impossible in Arkansas. Van later rose to eminence as a writer on finance. Freeman Conaway had hailed from Brooklyn, and he and Bryson Bruce, from Garden Grove, were legislative reporters. Cyrenus Cole did his turn as reporter, and later wrote editorials, but finally dropped down to become a congressman which better suited his sluggish temperament.

When I had transferred to the Journal, in Sioux City in 1890, the city desk went to Thomas Dawson, who later rose high in diplomatic circles, and about the same time came his brother Allen, whose brilliant career is well known. Frank Bicknell, who loved writing for its own sake and finished in a Carolina logging camp, came after, and in due time the versatile Leon Brown, now retired to a farm. I never got over a certain rivalry with the latter, because out of later factional zeal, Bailey of Britt denounced me as "the biggest liar in Iowa," but added in print "except Leon Brown," which irked me. Then there was in the business office at the right hand of "Uncle Dick" one G. Fred Selleck, out of whose barn storming with vaudeville came his love of sports; and E. A. Sciple, "Cordy" Keeler, Ernest Sherman and later Frank Lyman. Sometimes Col. W. S. Moore turned from typesetting to writing.

The brilliant understudy of the editor-in-chief was William A. Jones, diligent and dilettante, who came into the game by the back door and by way of tutoring in the family. He continued to write just as Ret would have written until "Uncle Dick" moved up-stairs to do the editing meat axe fashion. Leigh Hunt took Jones to Seattle when he invested his Asiatic fortune in a great newspaper venture, long after he had been adjudged a failure at Ames as college head. There was another Jones-"Deacon" we called him to distinguish him from the "professor"-the tyrant of the chapel above. He had help in the make-up from Henry Uetz, a member of this Pioneer club, and from Arthur John Bisnett, who organized rowing regattas on the Des Moines river.

The clock tower was indeed a veritable storm center fifty years ago. The political power that emanated therefrom was either courted or feared. The streams from its presses were not 
large but they went far. However, harsh the criticism directed that way, it was recognized generally that the output, in all of its phases, was clean and wholesome, of unquestioned loyalty to American ideals, in literary quality free from the vulgar or erotic, always acceptable at the club or by the fireside.

I do not mean to leave the impression that out of this little circle of which I have been speaking came all that was worthwhile or meritorious. The field was broad and fertile. Good material came to the mill and strong characters were fashioned. The experience of the caustic John C. Kelly on the Leader helped him to build the Sioux City Tribune. Henry Jones learned all he knew on the Leader and for years was the factotum of the Washington Post. Sam E. Carroll, who started with me on a county seat weekly, did a turn on the Leader and came to full stature in Iowa City and Keokuk. A kindly soul was Ed Skinner on the News, and he kept on into the halcyon days of "Billy" Hale. A sour partisanship is all that kept Henry Shaver from becoming great. Joel Witmer Jr. showed he had excellent newspaper material. Carroll Wright had tried his hand at the newspaper game, and so had Phil Kell, and others, I have yet to mention. It would be a pleasure, but take me too far, to pay proper tribute to the versatility of W. W. Witmer, city builder, publisher and editor.

No one of the gang of "scorpions of the press," as he called them, could forget the original and prolific Al W. Moore, who culled from a rich experience. His delight was to tell of the time when he was a brakeman on the "Q," and on terms of familiarity with Tom Potter, its great manager. Al just missed, by a drink or two, becoming a great writer of newspaper humor.

Because it was only a little way from the very beginnings, young reporters like myself, learned to know most of the old timers whose fingers were still a little inky. Hoyt Sherman never got entirely away from his newspaper instincts, and his brother Lampson recalled the drudgery of first print shops in Des Moines. W. H. Merritt, postmaster, and Daniel E. Finch, United States attorney, got valuable schooling in the sanctum. Wesley Redhead had been a "printer's devil" before he became 
a bookseller and coal baron. His partner, R. T. Wellslager, had been a country editor. I climbed to the top story of their Court avenue store to get news of North Des Moines doings from the pugnacious John MacVicar, who was their wallpaper salesman. Tradition lingered of the going forth of Stilson Hutchins to become a Washington publisher, of Frank Palmer to Chicago, and of George Parker to become a presidential secretary.

Then there was Gerit Van Ginkel, a Pella product, printer, gardener, coal digger and builder of things. He did me the honor to say that without my help in boosting-not always with strict adherence to truth-he never would have gotten started the first completely successful electric streetcar system in America.

Almost any day you could meet at an alley corner the amiable Barlow Granger, who would take a fresh chew and tell of the first twinkling of his Star. In his home in what is now your Pioneer Park I sat by his fireside and noted the walnut wainscot and ample hearth. I led him to recount in picturesque language the story of politics and newspapering in York state when he set type at Albany. His blood quickened when he told of the fights of Thurlow Weed and Horace Greeley. When he came to the point of telling what he thought of the latter his good wife tapped him gently on the arm and reminded him that Greeley had been dead a long time, which stopped the flow of profanity.

You do not think of Frederick W. Lehmann save as one of the great lawyers of Iowa and Missouri; but I have personally carried "copy" from his office that later turned up as editorial. The same hopper had been sometimes fed by the eloquent John S. Runnells, and by the much loved Judge George G. Wright, which two, with Dan Fitch and Dr. Hutchins adorned every banquet program.

The versatile James Wilson, familiarly the "Tama Jim" of agricultural fame, slipped into and out of the newspaper offices and left his marks. Over at the Newspaper Union office I leaned over his battered desk and listened to some forgotten Indian tale by A. R. Fulton, whose history is now rare. I swapped news leads with L. F. Andrews, the veteran correspondent, whose wife had also done her turn in writing, 
and was honored as last of the "real daughters" of the Revolution in Iowa.

Many others there were with print shop education or dabblers in literature. J. E. Williams and John Blair, who had struggled with the Journal, were doing other things. J. P. Bushnell had a passion for getting out directories. Tac Hussey had poetry and archery as side lines. A. L. Frisbie was willing, on call, to recite some of his own best verses. Mike King, past master of ward politics, had tried his hand at editing. Thos. G. Orwig kept up writing in one way or another. Wm. H. Fleming, even then a veteran newspaper man, could recall any date within the half century. P. P. Ingalls and Porte $\mathrm{C}_{\text {.. }}$ Welsh, born iconoclasts, spoke for the "Under-privileged" and hurled verbal dornicks at all who had savings bank accounts.

These all were moving figures in the picture I have tried to give you as I saw it after the first primitive mixing of the colors. Yet even when we had five a day there was room for other than the daily papers.

The making of "ready-prints" for country weeklies was inaugurated by the State Printing company, organized by Messrs. Gue, Redhead, Casady and others. It had become the Western Newspaper Union, at that moment directed by the pompous W. H. Andrews, who afterwards tried to make typewriters in Connecticut.

The Homestead was on its checkered career. At a later time when the auctioneer was calling for bids, the courtly Gov. B. F. Gue leaned over an imposing stone and told me of its history, as he had once or twice been its editor. Fifty years ago it had already passed from that shadowy figure, Wm. Duane Wilson, who had brought a little farm journal from some place in southeastern Iowa, and helped it grow until George $\mathbb{A}$. Miller gave it its final name. Little did we dream that a nephew of this founder was to be head of Princeton University and president of the United States. Henry Wallace, was on his way to become the farm philosopher of Iowa. I had heard of him when he was my newspaper neighbor with a page in the Madisonian at Winterset.

The name is about all that most will recall of a publication called The Million. "Free Trade" was the strange device emblazoned on its banner. 
To tell about it I can best do so by starting later and retracing the story. At a dinner given by W. W. Witmer in his Savery Hotel, in honor of Albert B. Cummins when the latter had become Senator, I started things off by reminding them of the time when as heads of the electoral tickets of their respective parties, these two men covered the state with joint debates. I hinted that each one had almost but not quite converted the other on the tariff issue. They accepted the cue and followed with stories of the debates. There was astonishment once when they drove into town together, and after soundly denouncing each the other, they turned in at one hotel room. But both were gentlemen of the old school, and well matched. Tariff discussion was a real need. The issue had been clouded. Had not an Iowa republican platform solemnly said that "we favor a wisely adjusted tariff for revenue" and that at a time when the Democrats were not very certain about anything? There had been rejoicing in high tariff circles when Judge Wright as champion of the American system of Hamilton, Clay and Lincoln, triumphed over Allison whose record in the lower house made him suspect of tariff heresy which he had brought over from Ohio.

Clarifying the tariff issue was a real job. Some of it was done in Des Moines. Here was the fount from which issued streams that near the close of the century were to almost sweep away the foundations of American agriculture and industry. The doctrine of free trade, or lower tariffs, had been nurtured in the Leader office from early times. On this point the newspaper deserved its name. It was not a new issue, but it flashed out with a fresh consciousness of class interests aroused by economic disturbances.

The prophet of the revived cult made a place for himself as sub-editor of the Leader, but sought to establish The Million as his personal organ. This was Henry J. Philpot, a prince of propagandists, a quiet, studious, dreamy person, an ideal oneidea crusader. Most of his ideas came from across the sea. The customs tariff, so he said, was everything the matter with a distressed nation. His talk was of tariff rates so low that he was heard in the Cobden club, and European intellectuals were asking where on the map was this place called Des 
Moines. The Million made a big stir. But the time and place were against the argument. The Million ceased to be.

Iowa never had any more delightful orator nor more appealing iconoclast that Gen. James B. Weaver, who at this time and in company with his friend, E. H. Gillette, was driving furiously in their Iowa Tribune at anything and everything that seemed to be not in harmony with high ideals of civic duty. The fearless general made good use of the abundant material lying loose all around. The plant finally went to Uncle Thomas Meredith, whose son made the paper over and made it pay. But the sword thrusts of Weaver, like the cannon shots of Philpot, left marks not yet obliterated.

An unworked pasture in the newspaper field had been overlooked, and John E. Clary was first to discover it with his Saturday Mail, and promptly Henry Persinger matched it with his Times. They specialized in silk stockings and high hats, and in card parties and weddings, but later the two Saturday papers were consolidated. At the height of their popularity with the society-minded people, Mose Jacobs brought his copperplated throat into open air broadcasting at Fourth and Walnut and laid foundations for a small fortune a dime at a time.

When Judge C. C. Cole was not politely entertaining a distinguished guest he put in some time on a law journal. Out on the edge of the prairie the Drake Delphic, or something of the sort, was piloted by C. G. Saunders, who was later to come back from Council Bluffs as a state senator. The exsoldier rights were guarded by Capt. W. T. Wilkinson in the G. A. R. Advocate. There were temperance journals, but none of them made a noise equal to the opposition of the StaatsAnzeiger and its spicy editor, Col. Joseph Eiboeck. One could not be on the firing line as reporter very long without meeting up with Elder D. R. Lucas, who had a church paper, though he loved more to "wave the bloody shirt" on the political stump.

The political merry-go-round of the state capital made this a fine field for correspondence work, regular or occasional. Fred Faulkes came over often from Cedar Rapids with his pockets filled with hand grenades. J. W. Bopp hailed from Fayette County when the miller of Clermont became governor 
and he ably exploited the new deal of the times. Emerson Hough essayed the role of representative of a Chicago paper, but turned over his job to me when he set out to write books. And so they came and went. But many who came on one errand or another lingered or returned. In this group was Sidney Foster, J. A. T. Hull, Edward C. Chassell, Don Donnan, Welker Given, Geo. H. Nichols, Samuel F. Stewart, Charles Beardsley, Ben Blanchard, John L. Brown, Henry Wilcox, Chas. Aldrich, Wm. H. Fleming and many others of the graduates from the case and the rule. Editors were almost always printers, and editors easily shifted to politics and other activities.

Keeping history straight leads me to a very personal note. I have a letter from my brother to my sister which she gave me. Thomas, the brother, in this letter dated February 8, 1882, told of his work on the Iowa State Leader and said he had turned down an offer to go as clerk in the law office of Wright, Cummins \& Wright because he had been given a raise of $\$ 4$ a week on the Leader. I know of but one other who labored in that den, in the old Exposition building, and that is Ed Finch, who is present and doubtless well remembers him.

With this letter is a copy of another in which this same young man, rather fresh from the Dallas County cornfields, was complimented in a letter written in Berlin by Samuel $\mathrm{L}$. Clemens on having been made manager of the New York publication house of that author. His association with Mark Twain long continued.

I could have had no purpose pertinent to this occasion in intruding this personal mention, but for the evidence on the letterhead that my brother used when he wrote his sister. It reads:

"Established in 1848. Paid up capital $\$ 100,000$. Iowa State Leader Co., Pubs. L. W. Goode, president; J. S. Polk, treasurer; F. M. Hubbell, secretary."

Yes, they had a hand in making newspapers as well as using them. I offer this, lest we forget.

Back to the main story. There was always a flutter when the grandiose J. Ellen Foster swept into town with a hatful of new ideas of quality for good stories. We enjoyed the hub- 
bub when Helen Gougar got a date to talk temperance in a legislative hall. Susan B. Anthony had ceased to make the rounds, but Matilda Fletcher was popular and courted publicity. Pauline Given had done real daily newspaper work before she joined with the swarthy Al Swalm and went forth to see the world. Leo Chapman, broken in health, came back to visit his old workshop and introduced his wife Carrie Lane, the versatile north Iowa schoolma'am who as Mrs. Catt is today a world figure. Nettie Sanford brought all sorts of stories to the desk, though she had teamed up with "Old Grizzly" Chapin of Marshalltown and was working on her anecdotal history of Polk County from which you heard excerpts read two years ago. A reporter had to know Mrs. Coggeshall and Mrs. Miller, zealous in work that interested women. At that time or later Ella Hamilton had been conducting a magazine for teachers. Other women appeared in the picture occasionally-Mattie Cope and Carrie McAyeal, who did "readings" in county seat towns; R. Anna Morris, Alice Hopper, Georgia Warrick, May Goodrell and other teachers.

$\mathrm{Up}$ and down the creaky stairs of a score of newspaper offices-an elevator was never provided-came a steady stream from the slough-grass and tall-timber sections, whose inky fingers and shiny coats betrayed their vocation. Their workshops might well have displayed the Burns warning:

"A chiel's amang you taking notes,

And, faith, he'll prent it."

There is no higher office than that of recorder of current history, but many of these worthy followers of splendid pioneers took a hand in the daily task of transforming romance into reality. Iowa was fortunate in the quality of these doubleduty ambassadors from crossroads villages and city beginnings.

Republicans relied on the versatile Geo. D. Perkins of Sioux City, Matt Parrott of Waterloo, and Sam Clark of Keokuk, to point with pride at platform making time. In like manner the Democrats felt sure of being able to roundly denounce or tremble with fear by the hands of D. N. Richardson of Davenport and M. M. Ham of Dubuque, perhaps assisted by "Glorious Ed" Campbell of Fairfield and Mayor Stubenrauch of Pella. 
To be state printer came George Roberts from Fort Dodge long before he qualified for interpreter of world finance, and George Ragsdale came after to do the printing. The Germans could always rely on J. Fred Myers of Denison and Theo. Guelich of Burlington. Johnson Brigham, after a long and honorable career in the daily field, was edging his way into the more agreeable one of magazine and library work. A. B. Funk was already started on his long and useful public career, taking generally two days each way from and to Spirit Lake. The dean of editorial philosophers was Howard Burrell of the Washington Press. "Billy" Payne had been clerk to Major Conger but was helping do the chores at Nevada. Harvey Ingham took time off from tracing Indian legends around Algona to go on an editorial excursion to Florida with the good fortune to meet and marry a Des Moines girl. Lafe Young and Charles Chase were visitors from Atlantic and John Mahin of Muscatine was on hand when temperance was the topic. J. W. Jarnagin was on all delegations from Poweshiek County. Lew Apple was doling out scandal at Panora. When prohibition was mentioned, Editor Wright came down from Charles City, and we dubbed him "Puff and Windy." The prince of boosters with uncut hair was Geo. T. Williams who hailed from Ida Grove. Des Moines, the state capital, was the common meeting ground of all who had much or little to do in the making of the state.

Mark Twain, himself an Iowa type-sticker, might have had some recollection of his days of river town wandering when he wrote:

"Look history over and you will see. The missionary comes after the whiskey-I mean, he arrives after the whiskey has arrived. Next comes the poor immigrant with ax and hoe and rifle; next the trader; next the gambler, the desperado, the highwayman, and all their kindred in sin of both sexes; and next the smart chap who has bought up an old grant that covers all the land; this brings in the lawyer tribe, and the vigilance committee brings in the undertaker. All these interests bring in the newspaper; the newspaper starts up politics and a railroad; all hands turn in to build a church and a jail-and behold, civilization is started forever in the land."

The one royal assignment in newspapering is that of the reporter. On his work all is built. His trail leads into the jungles of our complex culture. The reporter goes forth daily, 
like an explorer into darkest Africa, seeking the unknown, and great is the satisfaction if he returns laden with news. His work brings him into contact with all the worth-while currents of thought. He glimpses all the colorful lights of the changing scene. He must love his work. The endless highway from the unknown to the unknowable presented then as now and forever a fascinating panorama. Life itself is the great adventure. The true newspaper but mirrors reality.

Years ago the wise ones refused to believe it when they saw a streetcar go for the first time without mules up Fourth Street past Colchester place and as far as Rawson's. They just knew it wasn't so. I helped build the first Y.M.C.A. building. There was some strain of truth in the campaign. Prof. Frederick Phinney came shivering to lay on my desk his fantastic plan for a big band. It was impossible, but we boosted and pleaded and he went in triumph and with a big noise to the Columbian exposition. In a dusty corner of the state house Charles Aldrich showed his autographs, and with newspaper help the State Historical department became a reality.

It took a lot of hullabaloo to get professional baseball started. Everybody walked over to a vacant lot below the tracks where they used to hold county fairs. Not far away I once saw Barnum himself mopping the dust from his face as he stood under a striped tent and sold his book "Bugs and Other Humbugs" before the show in the big top opened. Mayor P. V. Carey was wrestling with charges for "herdics" and collections from the Whitechapel madames. There was mud aplenty in the campaign to get our residence streets out of the mire. Father Clarkson sarcastically contributed the suggestion that they pave Pleasant street, on which he lived, with slough grass. But we cut up telegraph poles and set the round blocks on pine boards. In a covey hole in the Clapp block I helped John E. Clary and a few others start the Merchant's Exchange, which survives under another name, and the spectacular "Seni-Om-Sed" carnivals were started on their way.

Opera house rivalry between Moore and Foster was a game in which we all took a hand. But it brought the great onesBooth, McCullough, Bernhardt, Salvini, Modjeska, Janaushek, Barrett. We laughed with Tim Murphy and Silas Robinson and Dolly Nobles. 
Feverishly we were building railroads, on paper, in the papers, and sometimes up the valleys. Judge N. M. Hubbard almost single-handed laid two little rails down from Ames. George Baker, now of the state board of education, carried the chains past Red Rock, and behold the Wabash. Fred Hubbell was dreaming of extending the Adel narrow gauge to almost anywhere that bonuses could be had.

The gold leaf had been laid on the capitol dome. The supreme court had ceased to go on travel. Rival companies were setting poles for telephones. First state fairs on the new grounds were at the mercy of the rain-gods. It had been a good story when Company "A" used a crowbar to break into the state auditor's office and carry out that official. Then came the impeachment trial by the senate which bankrupted the one-armed Brown and also several political careers. Marcus Kavanagh, now on the bench in Chicago, held forth in the old basilica near the railroad station that had been a church. John $\mathrm{H}$. Henderson, now lately retired after years of honorable service, had just come to the circuit bench. The senior McHenry charged the grand juries and doled out rough justice.

It was Gen. Josiah Given who presided as judge at the sensational battle when Gov. Larrabee was cited to court for having printed a leaflet in defense of his refusal to pardon a worthless scamp whose sobbing mother had stirred up a flood of tears. Great was the chagrin of the veterans of the bar when the governor shunted them all off and committed his case to the unknown Chas. A Bishop. I had first met this printerlawyer with a stick in his hand and his sleeves rolled up in a print shop in Cherokee. He had been long upon the supreme bench when he dropped dead at a bar meeting.

Everyone gasped when nearly all the city aldermen were put on trial for borrowing a few dollars more than the law allowed. But nobody demanded another court. A fine opportunity was passed up when the ticket buyers thought it not worth-while to prosecute "Doc" Aborn for failure to finish raffling off in his Montana lottery with the mortgaged Aborn House as grand prize.

Stephen V. White, pillar in Henry Ward Beecher's church, came to take a look at that famous total eclipse, staid awhile 
and came back often. The jokes cracked by "Laughing" Hatch shook the streets three blocks each way. If alive today he could make a fortune in Hollywood with that guffaw.

Then as ever we prattled of the arts of peace and went on parade with the prancing horses and the gold lace. It was a pleasure to help Gen. Given, veteran of two wars, set the flags for the last reunion of the survivors of the Mexican war. There was Col. Griffith, "Old Churubusco," waving one arm at the head of the thin line. They were still talking about the day that 50,000 survivors of the Army of the Tennessee marched up Walnut Street and cheered Generals Grant, Sherman, Pope, Myers and Belknap. They heard the speech in which the president pleaded for support for the free public schools as the safeguard of Americanism, the only speech he ever made.

Enough, perhaps too much, of this draft upon your recollections. Iowa, my Iowa, had been a state only fifteen years when I caught sight of the flowered prairies along the timber fringe less than a half-day's ox team journey away. The Iowa State Register had issued but three or four daily issues. Together we had known the post-war deprivations. I hope I may be pardoned for lingering lovingly over this middle period between the shacks and the skyscrapers. The rough tilling of the newspaper field had been done that a rich harvest might follow. Always the school started with "learning the case"-the rest came naturally in ordered sequence.

You have done well if you have gotten out of this rambling survey of the closing days of the romantic era, a little of the joy I have found. I shall go no further.

The times and circumstances are so woven into my soul that I have ransacked the chambers of memory without checking up. If accuracy is challenged, I shall not quarrel. The quest leads far. I have paused at the gateway to bypaths that would involve controversy. I did not take notes. Nobody ever does in the hurly-burly we call life. I have been speaking of the middle decade. I have tried to be fair. But each generation must care for its own.

In this time of which I have been talking, not alone in the print shops beneath clock towers or exposition domes, but in all the forums, there was the process of smoothing down the 
rough edges left by the slashing and sloshing of the frontiersmen. The frontier itself was receding. On Fourth of July we dragged out the covered wagons and the farewell address. We kept the bells to jingle at Christmas time. The surveyors had set their last stakes. The vigilance committees had been disbanded. County seat fights were no longer a popular pastime of politicians. Stage roads were being set over to section lines. No longer was heard the lusty crack of the bull whips of the backwoodsmen on tracks to "The Fort" for supplies. The sons of the trail blazers were sending forth from their new capital city a stream of rich cultural influence.

There was haste, there was rivalry, there was competition, big words and ugly were used. In the thrust and parry of editorial blades they were prodigal of good black ink. In their paper duels they gave resounding whacks; but as one these printer-editors challenged a showing of a land fairer than their Iowa, fields more fertile, lovelier youth or more dependable age, a more favorable environment for home making.

Print shop secrets were as sacred as the lodge password, but there was no secret about the agreement of the editors that in the valley of the big rivers there was a large measure of social security grounded on the principles their forefathers fought to establish, and they and their brothers fought to preserve.

A font or two of type and a hand press was equipment enough for the school of hard licks out of which came a class of printer-editors with hearts of oak. Many there were who turned aside to adorn other professions or to cultivate the useful arts. The print shop is a good starting place for almost any journey.

"Iowa-the affections of her people like the rivers of her borders flow to an inseparable union."

They meant it too and sent a hundred regiments to clinch the argument. They believed there were liberties to be prized and rights to be maintained, and woe to him whose patriotism was too weak to hold in leash the half-treasonable sneers at American fundamentals. The children of the captains of the claim clubs, mindful of the way of peace and prosperity, wrote high over a door in their new capitol, in the city of Des Moines, near the forks of the Coon, in letters of gold: 
"Where law ends tyranny begins."

Unafraid they flung to the breezes their slogans of loyalty. Banner devices that reflected the spirit of freedom were common property. A thousand Iowa Newspaper organs were attuned with fine unanimity to noble sentiments. In the daily record of events there was evidenced a wholesome American spirit. Out of such materials and in such fashion there was made a worthy state fitted into the pattern of an enduring federal union.

The printer-editors did their part. All honor to their memory.

\section{Wilson's Creek... a Young Girl Remembers}

This article is taken from a letter by Nancy Charlotte Emmaline Matchett, who, as a young girl, lived with her family near Wilson's Creek at the time of the Civil War battle. She wrote a letter to a newspaper in which someone she referred to as Knon had evidently printed a factual account of the famous Battle of Wilson's Creek, and tried to correct a misstatement the writer had made. This was written approximately 25 years after the battle, so it is based on memory.

Though the following account may not prove a pleasant experience for our readers, it is printed because it presents a valid picture of the all too common, but seldom discussed horrors of war.

I lived in one mile and a half of that battle when it was fought. My father was a prisoner on the battlefield during the fight. Knon makes a great mistake when he ses the dead was all buried before the night. I know that the Union soldiers lay on the battlefield without being buried for two weeks after the battle.

There was a company of [Union] men sent back after the battle with a flag of truce to bury the dead and was taken prisoner. Some of the citizens said they would help to bury them. The Rebel officers gave orders that the first men they found burrying them would be shot.

My father was right over the battlefield and seen the men laying and rottening in the hot sun. Some of them had bloated up twice their size and turned black. When they was took up their hair would drop off and you could tell wherever they had taken one [dead soldier] up in lots of places long into the winter. I was over the field myself and sen with my own eyes 
Copyright of Annals of Iowa is the property of State of Iowa, by \& through the State Historical Society of Iowa and its content may not be copied or emailed to multiple sites or posted to a listserv without the copyright holder's express written permission. However, users may print, download, or email articles for individual use. 